Louisiana State University

LSU Digital Commons

Faculty Publications

Department of Biological Sciences

$1-1-2007$

\title{
A new species of ponyfish (Teleostei: Leiognathidae: Photoplagios) from the Philippines
}

John S. Sparks

American Museum of Natural History

Prosanta Chakrabarty

American Museum of Natural History

Follow this and additional works at: https://digitalcommons.Isu.edu/biosci_pubs

\section{Recommended Citation}

Sparks, J., \& Chakrabarty, P. (2007). A new species of ponyfish (Teleostei: Leiognathidae: Photoplagios) from the Philippines. Copeia (3), 622-629. https://doi.org/10.1643/

0045-8511(2007)2007[622:ANSOPT]2.0.C0;2

This Article is brought to you for free and open access by the Department of Biological Sciences at LSU Digital Commons. It has been accepted for inclusion in Faculty Publications by an authorized administrator of LSU Digital Commons. For more information, please contact ir@lsu.edu. 


\title{
A New Species of Ponyfish (Teleostei: Leiognathidae: Photoplagios) from the Philippines
}

\author{
John S. Sparks and Prosanta Chakrabarty
}

\begin{abstract}
A new species of ponyfish in the genus Photoplagios is described from material collected in the Philippines. Photoplagios laterofenestra, new species, is distinguished from congeners by the presence in males of an expansive translucent flank patch in the shape of a cornucopia. Additionally, both sexes of the new species can be distinguished from congeners by body shape, pigmentation pattern on the upper flank, and length of the second dorsal-fin spine.
\end{abstract}

$P^{\prime}$ HOTOPLAGIOS comprises eight species: $P$. rivulatus, $P$. leuciscus, $P$. elongatus, $P$. klunzingeri, $P$. stercorarius, $P$. moretoniensis, $P$. antongil, and a new species described herein. Members of Photoplagios are markedly sexually dimorphic. Males are distinguished from all other members of Leiognathidae externally by the presence of an expansive, translucent lateral flank patch or stripe. Internally, males are distinguished by dorsolateral lobes of the light organ that are hypertrophied and that extend slightly to extensively into the gas bladder, and by expansive lateral clearing of the silvery, guaninecovered gas-bladder lining (Sparks et al., 2005). Clearing of the reflective gas-bladder lining is directly correlated in placement to the speciesspecific translucent lateral flank patches or stripes. Gas bladder clearing facilitates the lateral emission of bacterially-generated luminescence via the flank patches (Sparks et al., 2005). Males of all species of Photoplagios are easily distinguished from each other by size, shape, and placement of the translucent lateral flank patch or stripe (Fig. 1). Species of Photoplagios have dorsolateral lobes of the light organ that extend to some extent into the gas bladder and by lateral clearing of the gas-bladder lining; however, both of these features are far less pronounced in females than in males (Sparks et al., 2005). Photoplagios adults generally have shallower bodies than other leiognathid genera, but the presence of a shallow body is not unique to the genus.

In the present study, a new species belonging to the genus Photoplagios is described from material collected from the Samar Sea in the Philippines. Placement of the new species within Photoplagios is discussed with reference to homologous features of the light-organ system, which includes the circumesophageal light organ and associated structures (e.g., clearing of the gas-bladder lining, transparent flank, opercular, and gular patches) that facilitate the transmission of bacterially-generated luminescence.

\section{Materials AND Methods}

Osteological features of the new species and related taxa were examined using radiographs and specimens cleared and stained (CS) for bone and cartilage (following Taylor and Van Dyke, 1985). Light organs were examined in situ or isolated to permit detailed morphological comparisons. Morphometric measurements were recorded to the nearest $0.1 \mathrm{~mm}$ using dial calipers. Standard length (SL) is used throughout. Vertebral counts exclude the ural centrum (=last half-centrum). The first caudal vertebra is here defined as the first vertebra bearing a definite hemal spine (Hubbs and Lagler, 1949). Vertebral and fin-spine/ray counts were obtained from radiographs. The terminal dorsalfin and anal-fin rays, which are branched to the base of the fin, are counted as a single element. Pored scales in the lateral line are counted in series from the dorsal margin of the gill opening to the caudal flexure. Scale counts should be interpreted as approximations, due to high intraspecific variability, irregular arrangement, the deciduous nature of ponyfish scales in preservation, and because small scale size and the degree to which scales are embedded make accurate counts problematic. Institutional abbreviations follow Leviton et al. (1985).

A principal components analysis (PCA) was conducted to identify shape-related differences between the new species and congeners. Digital images were taken from the left side of each specimen. Only specimens that were preserved unbent and of adult size were used in this analysis. Landmarks (putatively homologous points on anatomical structures) were chosen in order to best represent the external shape of the body (Fig. 2). The software tpsDIG2 (version 2.05, Rohlf, 2006, http://life.bio.sunysb.edu/ morph/) was used to digitize the landmarks on the images. Generalized least squares (GLS) Procrustes superimposition was performed to 


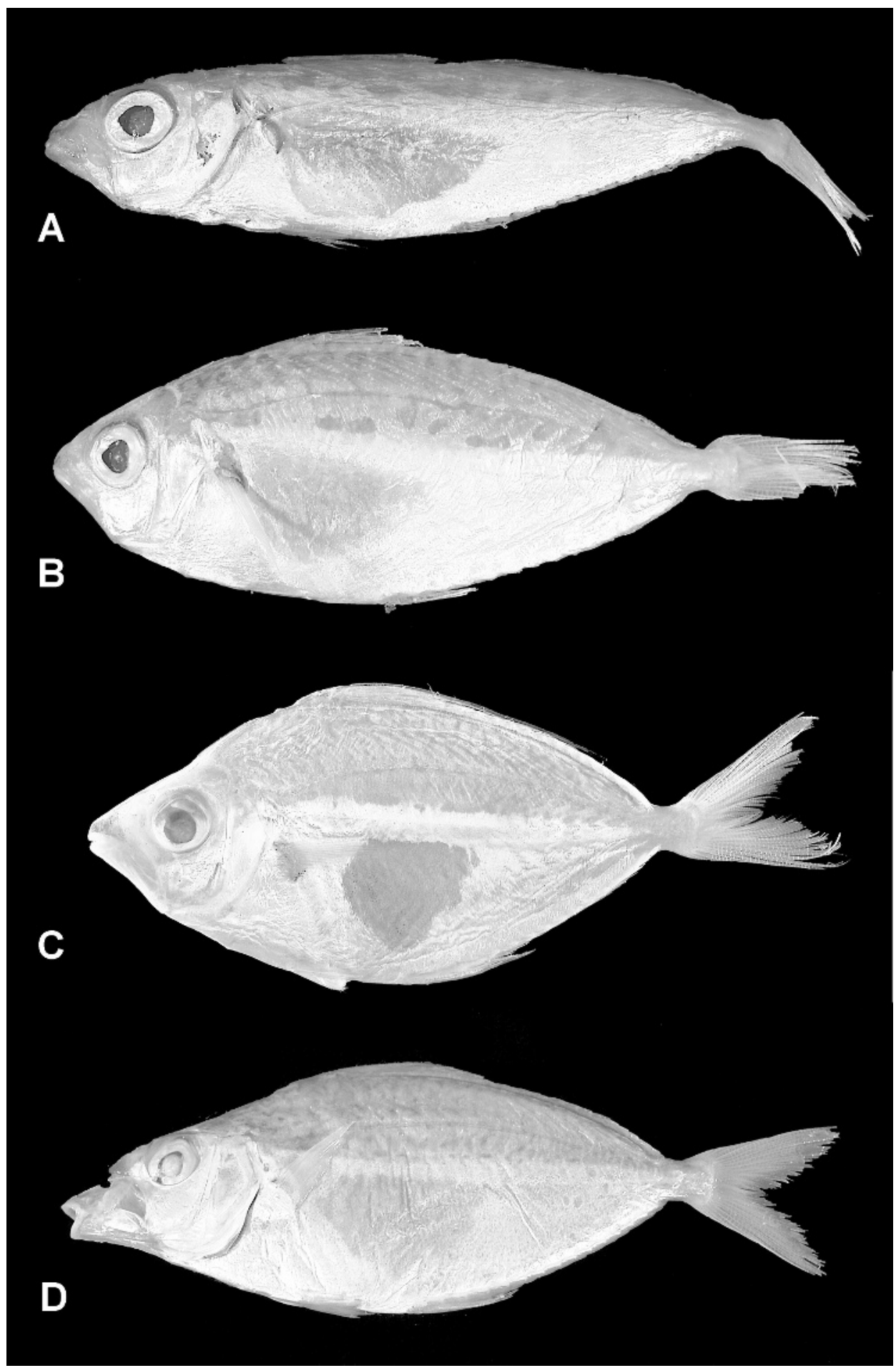

Fig. 1. Photographs of Photoplagios males, showing differences in shape of translucent flank patch: (A) Photoplagios elongatus (UMMZ uncat. [PVD 82-06/19a LE], $76.4 \mathrm{~mm} \mathrm{SL).} \mathrm{(B)} \mathrm{P.} \mathrm{rivulatus} \mathrm{(UMMZ} \mathrm{uncat.}$ [PVD 82-06/19a LR], $70.2 \mathrm{~mm} \mathrm{SL}$ ). (C) P. leuciscus (AMS I.22978004, $95.8 \mathrm{~mm} \mathrm{SL).} \mathrm{(D)} \mathrm{P.} \mathrm{klunzingeri}$ (NMW 68280, syntype, $75.0 \mathrm{~mm} \mathrm{SL}$ ). 


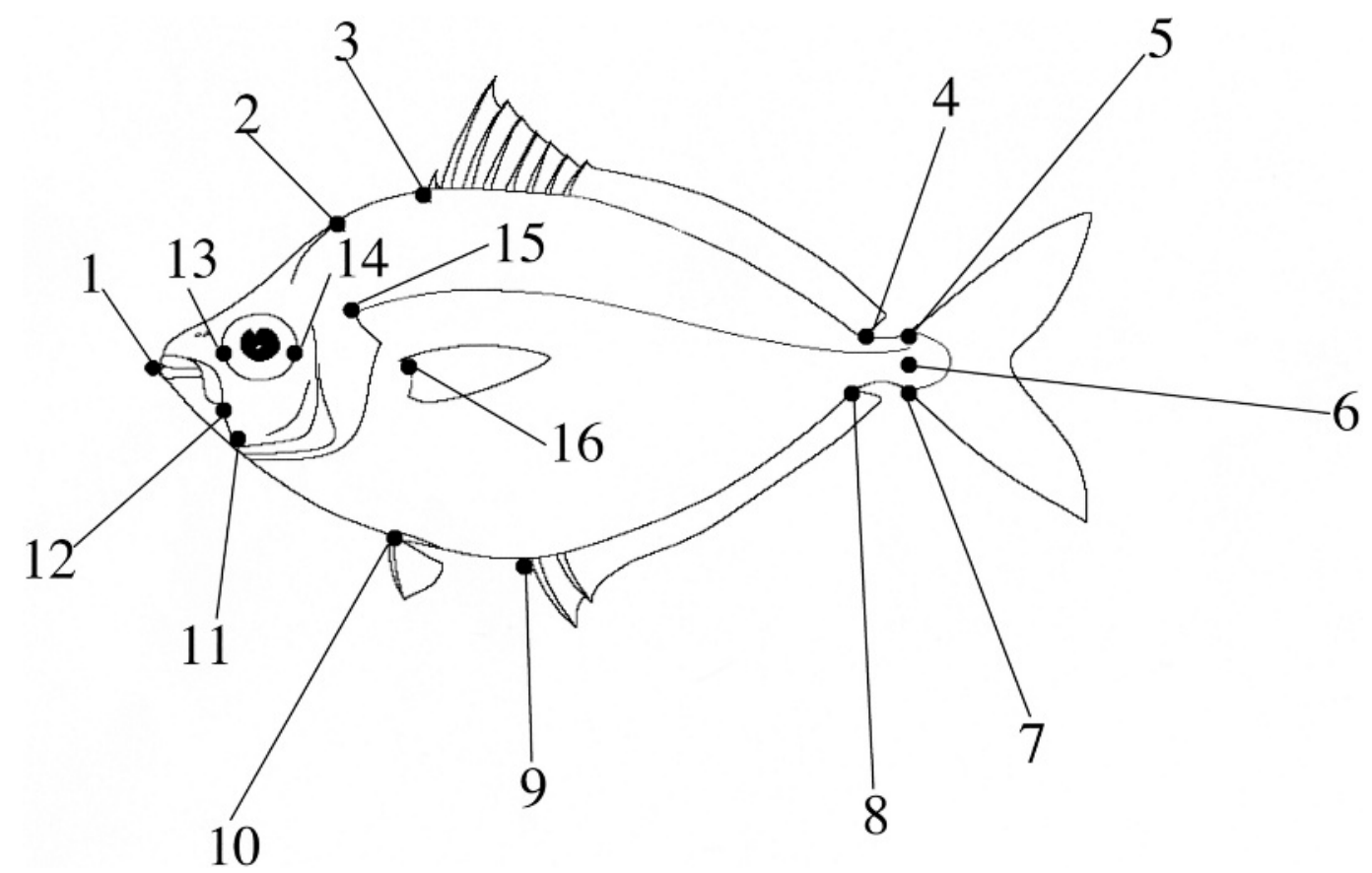

Fig. 2. Landmarks used for Principal Components Analysis: (1) rostral tip of premaxilla, (2) posterior end of nuchal spine, (3) anterior insertion of dorsal fin, (4) posterior insertion of dorsal fin, (5) dorsal insertion of caudal fin, (6) midpoint of caudal border of hypural plate, (7) ventral insertion of caudal fin, (8) posterior insertion of anal fin, (9) anterior insertion of anal fin, (10) dorsal base of pelvic fin, (11) ventral end of lower jaw articulation, (12) posterior end of maxilla, (13) anterior margin through midline of orbit, (14) posterior margin through midline of orbit, (15) dorsal end of opercle, (16) dorsal base of pectoral fin. Base figure modified from Nelson (2006).

remove size from the data. In the optimal superimposition, the distance minimized is the Procrustes distance, calculated as the square root of the summed squared distances between homologous landmarks (Rohlf and Slice, 1990; Goodall, 1991). This superimposition, and the PCA, was performed using PCAgen (Sheets, 2001, http://www2.canisius.edu/ sheets/morphsoft. html).

\section{Photoplagios laterofenestra, new species Figures 3-4, Table 1}

Holotype-USNM 387899, $115.2 \mathrm{~mm} \mathrm{SL}$, adult male, Philippines, Samar Sea, Carigara Bay, 0$86 \mathrm{~m}$ depth, $11^{\circ} 55^{\prime} 42^{\prime \prime} \mathrm{N}, 124^{\circ} 28^{\prime} 48^{\prime \prime} \mathrm{E}$ to $11^{\circ} 53^{\prime} 48^{\prime \prime} \mathrm{N}, 124^{\circ} 29^{\prime} 06^{\prime \prime} \mathrm{E}, 30$ April 1980, C. Ferraris.

Paratypes.-AMNH 238682, 2, $115.3-121.0 \mathrm{~mm}$ SL, data as for holotype; USNM 228508, 4, 115.9$127.9 \mathrm{~mm}$ SL, data as for holotype.

Diagnosis.-Males of Photoplagios laterofenestra are distinguished from all congeners by the presence of an expansive cornucopia-shaped translucent lateral flank patch. Both sexes of the new species can be further distinguished from $P$. elongatus and $P$. rivulatus, each of which possess a more or less bullet-shaped flank patch, by a deeper body (34.439.2 vs. $12.5-29.7 \%$ of SL in P. elongatus and $P$. rivulatus) and pigmentation pattern on the upper flank (vermiculate, with thin wavy lines forming semi-circles and oval shapes vs. larger rounded blotches in P. elongatus and P. rivulatus). Males and females of the new species can be further distinguished from P. leuciscus and P. klunzingeri, both of which possess a triangular flank patch, by the lack of a markedly elongate second dorsal-fin spine and the pigmentation pattern on the upper flank (vermiculate, with thin wavy lines forming semi-circles and oval shapes vs. speckled in $P$. leuciscus and P. klunzingeri). Adults of both sexes of the new species also grow to a larger size than congeners, except $P$. leuciscus.

Description.-Selected proportional measurements and meristic data presented in Table 1. A comparatively large, shallow bodied, and laterally compressed species of ponyfish. Dorsal profile slightly more convex than ventral. Deep- 


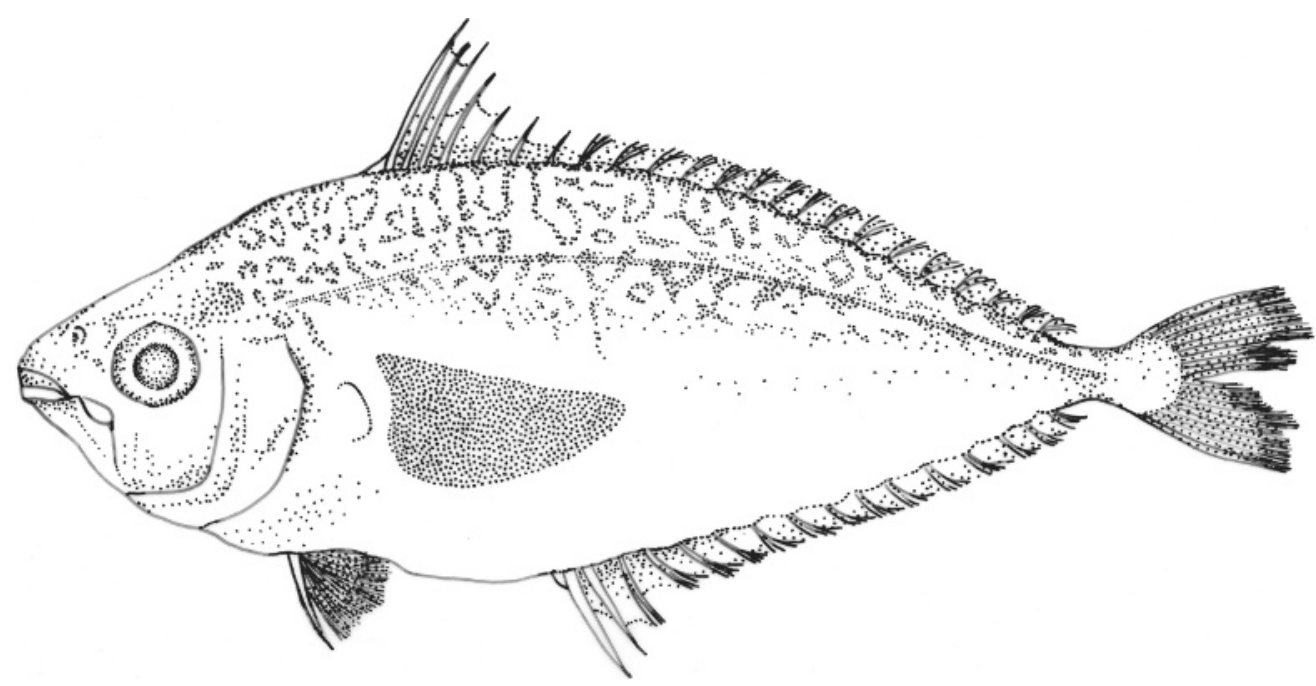

Fig. 3. Illustration of holotype of Photoplagios laterofenestra, USNM 387899, adult male, 115.2 mm SL, Philippines. Pectoral fin not illustrated in order to reveal lateral flank patch. Drawing by Annemarie Noël.

est part of body at vertical from dorsal-fin origin to pelvic-fin origin. Lateral snout outline nearly straight. Slight concavity present dorsal to orbit. Concavity much less pronounced than in more deep-bodied species. Concavity created by convergence of left and right supraorbital ridges dorsal to orbit, followed posteriorly by exposed rising dorsal aspect of supraoccipital crest (nuchal spine).

Dorsal-fin origin slightly posterior to vertical through pelvic-fin origin. Anal-fin origin near vertical through midpoint of body: approximately at vertical between last dorsal-fin spine and first dorsal-fin ray. Caudal peduncle slender and shallow. Mouth small and terminal, and directed slightly downward when protruded. Lips somewhat fleshy. Posterior margin of maxilla exposed and reaching vertical through anterior part of pupil as well as dorsal portion of lower jaw articulation. Eye large and circular (29-34\% of head length $[\mathrm{HL}])$. Sensory pores around eye moderately well developed. One canal on ventrocaudal aspect of orbit elongated and reaching preopercle. Nasal pores closely apposed and separated by only small bridge of tissue. Both nasal pores oval; anterior pore roughly half size of posterior pore. Preopercular margin weakly to moderately serrated; serrations concentrated along ventral and ventrocaudal margins. Ceratobranchial 1 with 13 elongate, triangular, and heavily denticulated gill rakers. Vertebral count 23 (10 precaudal + 13 caudal). Single supraneural present. Supraneural large and robust as observed through radiographs. Dorsal aspect of supraneural spine about equal in length to radius of orbit, whereas vertical (elongate) aspect about equal to diameter of orbit.

Dorsal fin with eight spines and 16 rays. First dorsal-fin spine very short (9-11\% of length of second spine). Second dorsal-fin spine longest, but not considerably longer than third or fourth spines (Fig. 3). Second, third, and fourth spines relatively robust, with third and fourth possessing serrations along their anterior margins that facilitates interlocking with preceding spines when fin erect. Remaining spines (V-VIII) more feeble and shorter. Anal fin with three spines and 14 rays. First anal-fin spine very short $(8-10 \%$ of length of second spine). Second and third analfin spines robust, and second only slightly longer than third. Third anal-fin spine possesses serrations on anterior margin that facilitates interlocking with second spine when fin erect. Bases of spinous portions of both dorsal and anal fins covered by ridges of tissue lacking scales. Pelvic fin short and not reaching origin of anal fin when adducted. Gap between posterior margin of adducted pelvic-fin and anal-fin origin about equal to length of pelvic fin. Caudal fin deeply forked.

Oral teeth long and villiform, and arrayed in narrow band of four to five rows. Teeth in lower jaw slightly recurved; those in upper jaw strongly recurved, almost parallel with roof of mouth.

All specimens comprising type series have lost most scales in preservation and following observations should be considered speculative. Chest, fins, and suborbital series appear asquamate. Scales present in nuchal region and below dorsal-fin origin in only some specimens. Lateral 


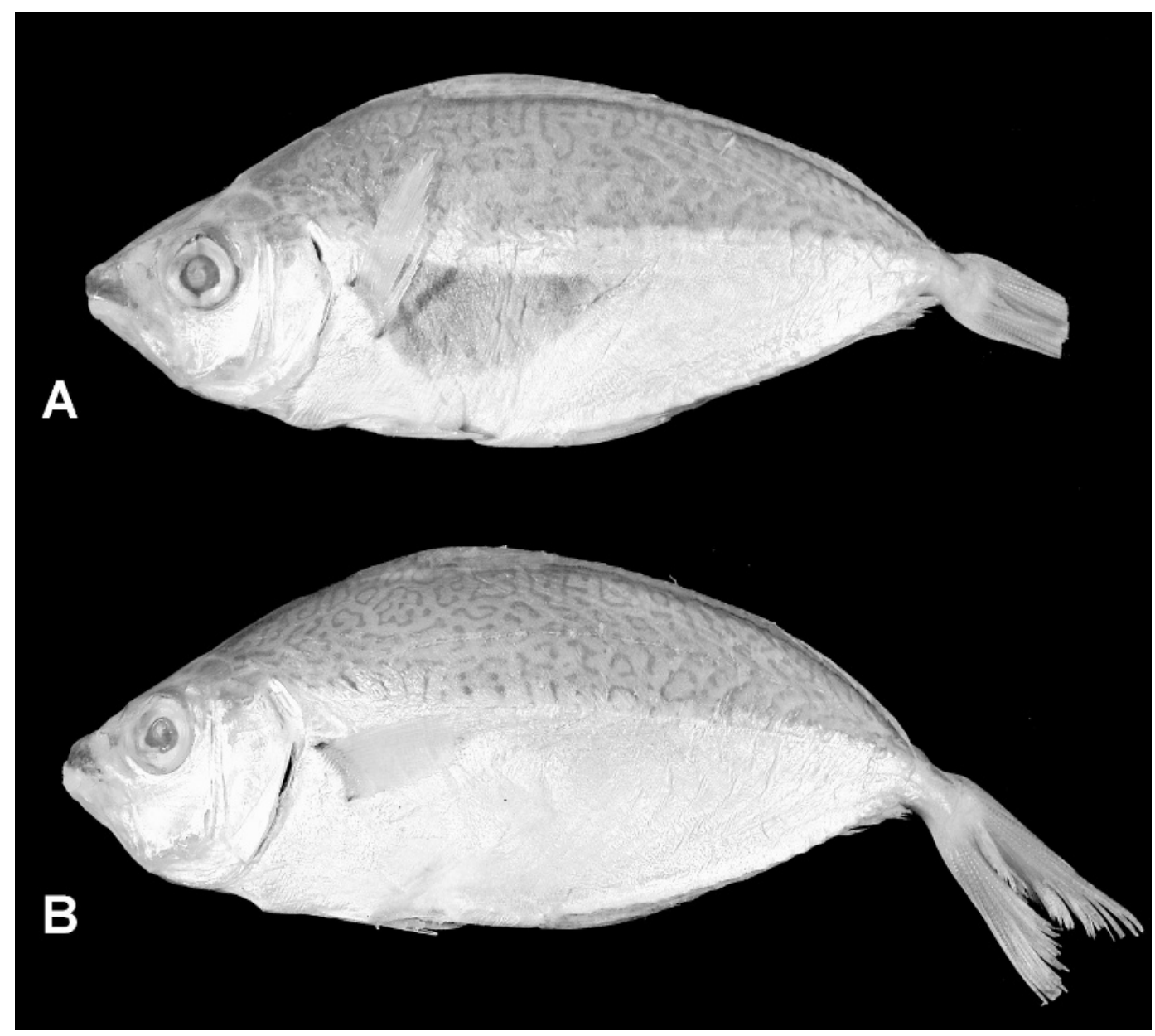

Fig. 4. Photoplagios laterofenestra. (A) Holotype, USNM 387899, adult male, $115.2 \mathrm{~mm}$ SL, Philippines. (B) Paratype, USNM 228508, adult female, $127.9 \mathrm{~mm}$ SL, Philippines.

line complete, extending from opercle to posterior margin of caudal peduncle, and comprising about 60 scales. Lateral line arches only slightly. Pores of lateral line well developed.

Sexual dimorphism.-Single male specimen, holotype, with large translucent patch (guanine-free region) on anterior flank in shape of cornucopia (Figs. 3-4). Translucent patch abuts pectoral-fin base. Translucent patch peppered with aggregated melanophores and extending longitudinally from pectoral-fin origin to midpoint of flank. Ventrally, patch extends to slightly below horizontal through ventral aspect of dentary. Translucent flank patch lacking entirely in females.

Pigmentation in preservative.-Body generally light brown above midline. Ventral half of body, from slightly above midline, covered in silvery guanine.
Gill covers and suborbital region silvery with guanine extending up to vertical through anterior margin of orbit. Most of area anterior to vertical through rostral margin of orbit lacks silvery guanine, except for scattered patches posteriorly on lower jaw. Dorsal markings vermiculate, usually comprising short irregular patterns; sometimes forming oval shapes dorsally and anteriorly (Fig. 4). Curved lines present near lateral line, occasionally appearing as oval shapes. Dark line present along entire base of dorsal fin and sometimes extending onto dorsal margin of caudal peduncle. Dark blotch, due to concentration of melanophores, present above upper lip (and sometimes includes upper lip) ventral to nasal pores, and extending posteriorly to exposed portion of maxilla. Distinct dark spot present on prefrontal region posterior to nasal pores and anterior to orbit. Concentration of 
TABle 1. MORPhOMETRIC DATA FOR Photoplagios laterofenestra $(n=7)$.

\begin{tabular}{lcccc}
\hline \multicolumn{1}{c}{ Character } & Holotype & Range & Mean & SD \\
\hline Standard length (mm) & 115.2 & $115.2-127.9$ & 120.0 & \\
Percentage of SL & & & & \\
$\quad$ Head length & 27.4 & $26.5-29.0$ & 37.2 & 1.82 \\
Body depth & 37.8 & $34.4-39.2$ & 43.9 & 0.79 \\
Predorsal length & 43.3 & $42.9-45.5$ & 56.3 & 1.78 \\
Preanal length & 54.9 & $54.6-59.4$ & 38.3 & 0.94 \\
Prepelvic length & 37.0 & $37.0-39.4$ & 13.5 & 0.36 \\
Head width (max.) & 13.5 & $13.2-14.2$ & 8.2 & 0.95 \\
Caudal peduncle length & 8.8 & $6.1-8.9$ & 3.5 & 0.39 \\
Caudal peduncle width & 3.0 & $3.0-4.2$ & 5.2 & 0.47 \\
Caudal peduncle depth & 5.5 & $4.7-6.0$ & 18.3 & 0.94 \\
Pectoral-fin length & 20.1 & $17.2-20.1$ & 11.6 & 0.94 \\
Pelvic-fin length & 12.3 & $10.5-13.2$ & & 1.81 \\
Percentage of HL & & & 34.7 & 1.78 \\
Snout length & 36.4 & $31.9-37.0$ & 31.4 & 2.61 \\
Orbit diameter & 31.3 & $28.7-33.7$ & 40.9 & 3.72 \\
Upper jaw length & 43.0 & $38.7-45.1$ & 51.0 & 2.80 \\
Lower jaw length & 52.8 & $48.0-58.5$ & 33.5 & 0.15 \\
Interorbital width & 34.8 & $30.3-38.9$ & 1.58 & 0.48 \\
Caudal peduncle length/depth & 1.6 & $1.3-1.7$ & 2.38 & \\
Caudal peduncle length/width & 2.8 & $1.5-2.9$ & & \\
\hline & & & \\
\end{tabular}

melanophores also present in pectoral-fin axil. All fins, lips, and interorbital and gular regions otherwise a pale, opaque gray.

Distribution.-Known only from single lot of specimens (originally catalogued as USNM 228508) collected from Carigara Bay, Samar Sea, Philippines.

Etymology.-Named in reference to expansive translucent lateral flank patch in males (from the Latin lateralis $=$ lateral $/$ side, and fenestra $=$ window). Specific epithet, laterofenestra, to be treated as a noun in apposition.

\section{DISCUSSION}

Photoplagios laterofenestra is most similar in external appearance, including both overall body shape and pigmentation pattern, to $P$. leuciscus and $P$. klunzingeri. The new species is distinguished from both $P$. leuciscus and $P$. klunzingeri by a shorter second dorsal-fin spine, pigmentation pattern on the upper flank (vermiculate, with thin wavy lines forming semicircles and oval shapes vs. speckled in P. leuciscus and $P$. klunzingeri), and the presence of an expansive cornucopia-shaped translucent flank patch in males (vs. a triangular patch resembling an inverted pyramid in $P$. leuciscus and $P$. klunzingeri). This translucent patch abuts the pectoral-fin base broadly (vs. not abutting the pectoral-fin base in P. leuciscus, or abutting the pectoral-fin base only at the anterior angle of the triangle in $P$. klunzingeri; Fig. 1). In addition to differences in the shape and extent of the translucent flank patch (Figs. 1, 3-4), P. laterofenestra is easily distinguished from both $P$. elongatus and $P$. rivulatus by a deeper body (34.4-39.2 vs. $12.5-29.7 \%$ SL in P. elongatus and $P$. rivulatus) and pigmentation pattern on the upper flank (vermiculate with thin wavy lines forming semi-circles and oval shapes vs. larger rounded blotches in $P$. elongatus and $P$. rivulatus; Figs. 1, 3)

A PCA of shape resulted in a PC1 that accounted for $67 \%$ of the variation among the five species of Photoplagios in which males are characterized by translucent flank patches. Principal component 2 and PC3 accounted for 10\% and $7 \%$ of this variation, respectively. The new species formed a distinct group from all other species on the plot of PC1 vs. PC2, with the exception of $P$. leuciscus for which there was a slight overlap (Fig. 5). Principal component 1 accounted for much of the variation among specimens in body depth between the nuchal area and the anal-fin origin. Principal component 1 also accounted for variation in relative body length among specimens. Principal component 2 accounts for some of the variation due to shortening of the nuchal, snout, and head 


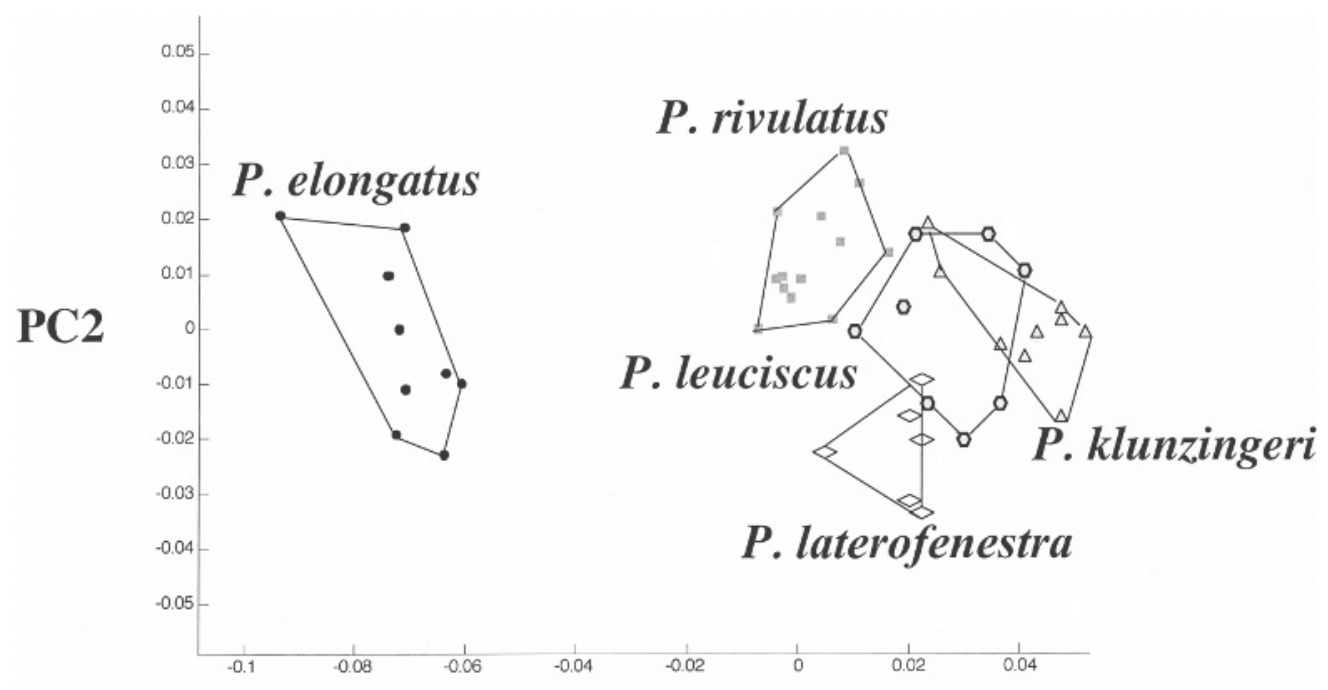

\section{PC1}

Fig. 5. Principal component analysis of species of Photoplagios in which males are characterized by a translucent flank patch (plot of PC1 vs. PC2). Photoplagios elongatus specimens are represented by black dots, $P$. rivulatus by squares, $P$. leuciscus by hexagons, $P$. klunzingeri by triangles, and $P$. laterofenestra by diamonds.

regions relative to the rest of the body. This assemblage of five species (including the new species) is monophyletic and recovered as the sister taxon to members of the genus in which males are characterized by a translucent midlateral stripe that is either continuous or comprised of numerous discrete windows (Sparks et al., 2005; Sparks, 2006).

\section{MATERIAL EXAMined}

Specimens are listed alphabetically by genus and species. For each species, type specimens are listed first (including number in lot), followed alphabetically by museum abbreviation and including number of CS individuals in lot.

Photoplagios elongatus: BMNH 1872.4.6.105, holotype; CAS 52602; LACM 42993-1; LACM 43584-1; SIO 83-55; USNM 55613; UMMZ 226771; UMMZ 240145, 2 ex. CS; UMMZ uncat. (PVD 82-06/19a LE).

Photoplagios klunzingeri: NMW 68277, syntypes, 4 ex.; NMW 68280, syntypes, 2 ex.; NMW 76008, syntypes, 4 ex.; NMW 76009, syntypes, 4 ex.; AMNH 44488; AMNH 44491; AMNH 44493; AMNH 44496, 4 ex. CS.

Photoplagios leuciscus: BMNH 1858.4.21.243, holotype; AMNH 237149; AMS I.22967001; AMS I.22978004; AMS I.34365015; ANSP 27525, holotype of Leiognathus vermiculatus; UMMZ 240125;
USNM 76609; USNM 191979; USNM 191991; USNM 307917; USNM 373280.

Photoplagios moretoniensis: QM I.1583, syntype, 1 ex.; AMS I.21700001; AMS I.22983001.

Photoplagios rivulatus: RMNH 1438, holotype; AMNH 34850; UMMZ 182938; UMMZ 240144, 2 ex. CS; UMMZ uncat. (PVD 82-06/19a LR).

Photoplagios stercorarius: USNM 55906, holotype; USNM 126395, paratype, 1 ex.; ANSP 33289, paratype, 1 ex.; CAS 42171, paratype, 1 ex.; CAS 17678; CAS-SU 20004, paratype; UMMZ 240138, 2 ex. CS; USNM 191996.

?Photoplagios (Leiognathus) oblonga: MNHN A6754, holotype.

?Photoplagios (Leiognathus) parviceps: MNHN A0580, syntype, 1 ex.

?Photoplagios sp.: MNHN 1988-0327.

\section{ACKNOWLEDGMENTS}

Thanks to S. Jewett, L. Palmer, K. Murphy, L. Parenti, and J. Williams (USNM), J. Leis, M. McGrouther, and T. Trnski (AMS), J. Johnson (QM), E. Mikschi (NMW), D. Nelson and P. Dunlap (UMMZ), M. Sabaj and J. Lundberg (ANSP), H. Walker (SIO), M. van Oijen $(\mathrm{RMNH})$, and D. Catania and W. Eschmeyer (CAS) for the loan of specimens in their care. D. Nelson was extremely helpful with the loan of material and the curation of specimens deposited at UMMZ. Thanks to M. Stiassny (AMNH) for 
providing specimens and to B. Brown, R. Arrindell, and D. Rodríguez (AMNH) for assistance with loans and radiographs. Thanks to $\mathrm{M}$. Dorsey and A. Nzeribe for assistance with the collection of morphometric data. We are grateful to A. Noël for producing the original drawing of the holotype. This work was supported by a grant (DEB-0444842) from the National Science Foundation.

\section{Literature Cited}

Goodall, C. 1991. Procrustes methods in the statistical analysis of shape. Journal of the Royal Statistical Society, Series B (Methodological) 53:285-339.

Hubbs, C. L., And K. F. Lagler. 1949. Fishes of the Great Lakes region. Cranbrook Institute of Science Bulletin 26:1-186.

Leviton, A. E., R. H. Gibbs, JR., E. Heal, and C. E. DAWSON. 1985. Standards in herpetology and ichthyology: part I. Standard symbolic codes for institutional resource collections in herpetology and ichthyology. Copeia 1985:802-832.
Rohlf, F. J., AND D. E. SLICE. 1990. Extensions of the Procrustes method for the optimal superimposition of landmarks. Systematic Zoology 39:40-59.

SpARKS, J. S. 2006. A new species of ponyfish (Teleostei: Leiognathidae: Photoplagios) from Madagascar, with a phylogeny for Photoplagios and comments on the status of Equula lineolata Valenciennes. American Museum Novitates 3526:1-21.

Sparks, J. S., P. V. DunlaP, AND W. L. SMith. 2005. Evolution and diversification of a sexually dimorphic luminescent system in ponyfishes (Teleostei: Leiognathidae), including diagnoses for two new genera. Cladistics 21:305-327.

TAYlOR, W. R., AND G. C. VAN DyKe. 1985. Revised procedures for staining and clearing small fishes and other vertebrates for bone and cartilage study. Cybium 9:107-119.

DEPARTMENT OF ICHTHYOLOGY, DiVISION OF VERTEBrate ZoOlogy, AMErican Museum of NATUral History, New York, NEw YORK 10024 . E-mail: (JSS) jsparks@amnh.org; and (PC) prosanta@ amnh.org. Send reprint requests to JSS. Submitted: 14 Sept. 2006. Accepted: 31 Jan. 2007. Section editor: C. J. Ferraris. 